\title{
PHOTOINDUCED SURFACE RELIEF MODULATION IN AMORPHOUS CHALCOGENIDE THIN FILMS DURING HOLOGRAPHIC RECORDING
}

\author{
U. Gertners and J. Teteris \\ Institute of Solid State Physics, University of Latvia, Kengaraga 8, LV-1063 Riga, Latvia \\ E-mail: gertners@gmail.com
}

Received 26 August 2009; accepted 19 March 2010

\begin{abstract}
In this report the study of direct holographic recording of the surface relief gratings on amorphous chalcogenide thin $(0.5-$ $10 \mu \mathrm{m})$ films is presented in view of the light polarization state. Recording was performed on $\mathrm{As}_{2} \mathrm{~S}_{3}$ by $532 \mathrm{~nm}$ wavelength laser light. Because of direct surface relief formation, its efficiency may also depend on the softening temperature of the film material, which was studied using additional incoherent laser light for extra illumination during holographic recording. The results have shown that the efficiency of surface relief formation is many times higher in the case of extra illumination by additional incoherent light during recording. The mechanism of the direct recording of surface relief on amorphous chalcogenide films based on the photoinduced plasticity is discussed.
\end{abstract}

Keywords: amorphous chalcogenide films, holographic recording, softening temperature, surface relief, polarization

PACS: 42.40.Eq, 42.40.Lx

\section{Introduction}

The key element for the production of surface relief holographic optical elements is photoresist or light sensitive material. The changes in local chemical properties, optical parameters, microhardness, viscosity, and some other characteristics [1-3] induced in a resist material by light or e-beam exposure enable the surface relief structuring by wet or dry etching. Therefore this process includes two steps: recording and development by etching. Due to polarization-dependent anisotropic changes in resist material, such as opto-mechanical [4], M-shaped [5], or anisotropic crack [6] deformations during exposure it is possible to obtain a structured surface relief optical elements without etching.

A number of organic and inorganic materials have been studied for direct surface relief formation during a process of exposure by light or e-beam $[2,7,8]$. This is very promising for practical applications, since makes it possible to simplify the technology of surface patterning.

Apart from that, we report here the surface relief formation during holographic recording in amorphous chalcogenide semiconductor thin films. A number of studies have been carried out on the photoinduced structural transformation in amorphous chalcogenides dur- ing the past few years $[7,9,10]$, but in this case particular attention is given to the polarization state of exposure light.

Intensity distribution of the two coherent equal intensities P-polarized beams' interference can be approximated by sin function: $I_{\text {local }}=I_{\max } \sin ^{2}(\pi x / \Lambda)$, where $\Lambda$ is the period of light interference and $x$ is profile coordinate. From this formula one can see that the local intensity of the light periodically varies from zero to $I_{\max }$, i. e. there exist places where light intensity equals to zero. In the case of holographic recording and direct surface relief formation during the exposure process that means that there always exist local unexposed areas on the sample which do not participate in surface relief formation process and, moreover, disturb the relief formation efficiency. Can we change this situation and how? What happens if we extra illuminate sample by additional incoherent laser light with intensity $I_{0}$ during recording process? We keep the same local light gradient and increase the total local intensity in the range from $I_{0}$ to $I_{0}+I_{\max }$ - expose also the places where local intensity of the recording beams is equal to zero, thus decreasing the softening temperature and probably increasing the efficiency of the surface relief formation during holographic recording. Since there is a direct surface relief formation, its efficiency may also 

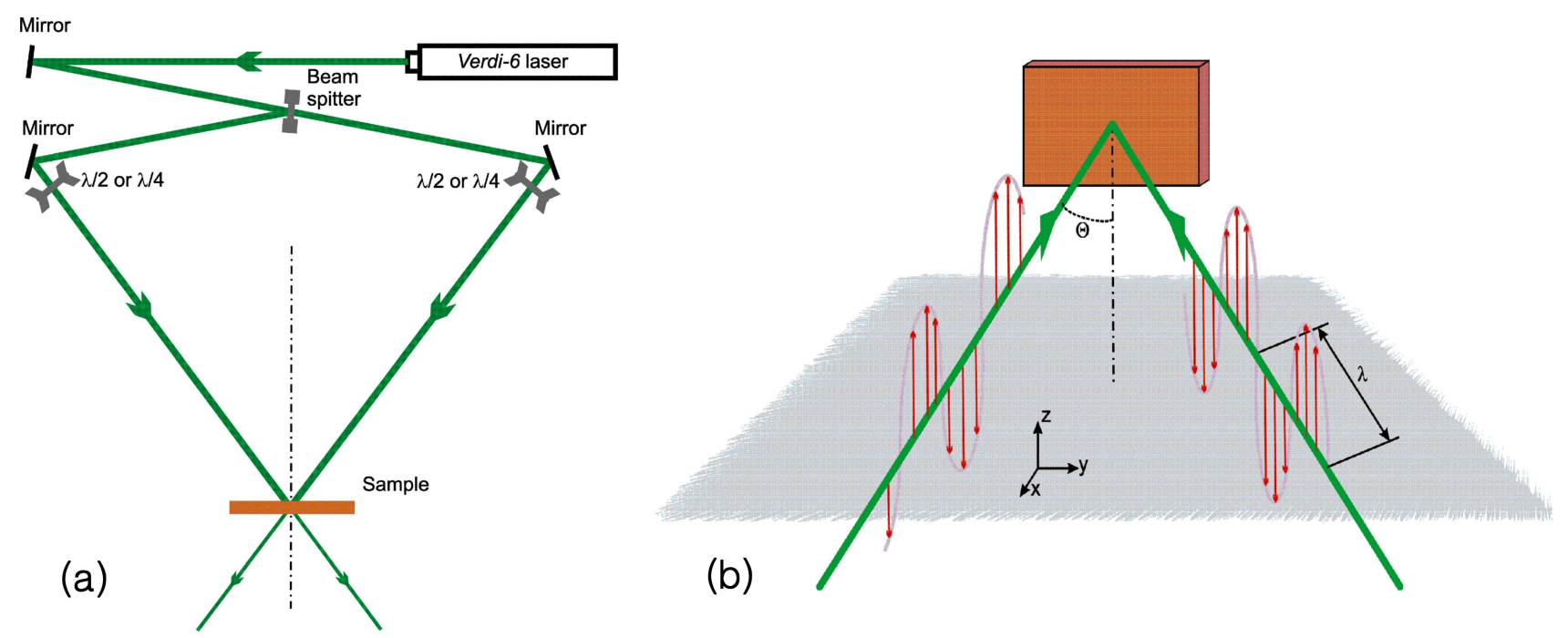

Fig. 1. (a) Experimental set-up for the holographic recording experiments (recording was performed by YAG Verdi $6532 \mathrm{~nm}$ laser), (b) polarization is defined by $x-y$ plane where both recording beams are located - in this case both laser beams are vertically polarized, i. e. are in $S$ polarization state.

depend on the softening temperature of the sample. The main task of this report was to investigate this dependence using additional incoherent laser light for extra illumination during holographic recording.

\section{Experiment}

Amorphous films were obtained by thermal evaporation in vacuum onto glass substrates. Thickness of the sample was controlled in real time by diode laser and it was from 0.5 to $10 \mu \mathrm{m}$.

The surface relief formation experiments were performed using a holographic recording system (see outline in Fig. 1(a)) where Verdi 6 laser $532 \mathrm{~nm}$ wavelength light was used for recording. Diffraction efficiency $\eta$ was controlled in real time by measuring the 1 st order intensity of the reflected and transmitted recording beams. During the holographic recording by measuring the transmission diffraction efficiency (DE) $\eta_{\mathrm{T}}$ the changes in volume were controlled (like those in absorption and refractive index) and by measuring the reflection DE $\eta_{\mathrm{R}}$ the changes in surface relief modulation were assessed. The volume gratings also affect the reflection DE, however their contribution is insignificant (see [2]) and will not be discussed here.

The recording efficiency is defined as the slope of the 1 st order polynomial equation $\eta_{\mathrm{R}}=c_{0} t$, i. e. $c_{0}=$ $\Delta \eta_{\mathrm{R}} / \Delta t$, where $t$ is time of exposure. The enhancement of relief formation is defined as the efficiency of recording with extra illumination divided by that without extra illumination:

$$
\left(\eta_{\mathbf{R}}\right)_{i} /\left(\eta_{\mathbf{R}}\right)_{0}
$$

The polarization state is defined by the plane where the electric field oscillates versus the $x-y$ plane where both recording beams are located (see Fig. 1(b)). Therefore, if both planes have the same orientation this means that the light has a $\mathrm{P}$ polarization state; otherwise, if both the planes are at an angle to each other (e.g. $10^{\circ}$ ) we say that the light has a $10^{\circ}$ polarization state; if this angle is $90^{\circ}$, there is $\mathrm{S}$ polarization of the light.

\section{Results and discussion}

Figure 2 shows typical diffraction efficiency changes with time (up to dashed vertical line). As the absorptionand refractive-index-photoinduced changes in resist material are comparatively fast processes, transmission diffraction efficiency (DE) $\eta_{\mathrm{T}}$ reaches its maximum ( $\sim 55 \%)$ very fast. At the same time with $\eta_{\mathrm{T}}$ decrease, reflection DE begins to grow linearly - the light starts forming surface relief structures. And simultaneously with surface relief amplitude increasing $\left(\eta_{\mathrm{R}}\right.$ growing up), because of the extra length disturbing the transmission $\mathrm{DE}, \eta_{\mathrm{T}}$ continues to decrease. Is this process reversible? Yes, it is! By shifting local light distribution by half period (in Fig. 2, after dashed vertical line), reflection DE falls down (erasing process) and then again is increasing with time (corresponding to new relief formation). This process is repeatable many times and indicates that the surface relief is a product of the local light-induced mass transport.

Figure 3 shows dependence of the recording efficiency on its parameters, i.e. the efficiency of surface relief formation versus intensity of the incoherent light 


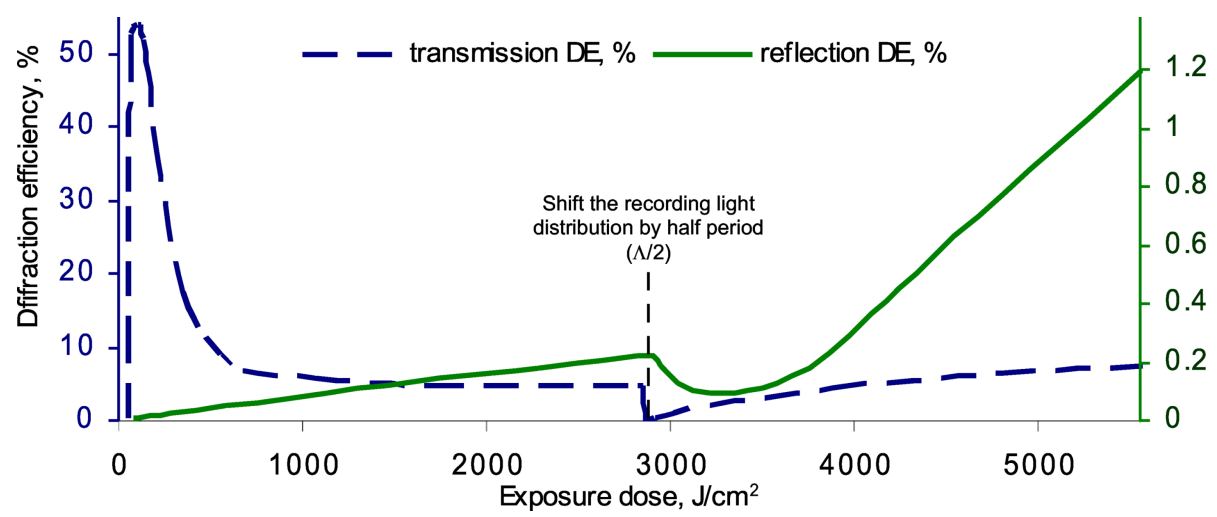

Fig. 2. Diffraction efficiency ( $\eta_{\mathrm{T}}$ values on the left ordinate axis, $\eta_{\mathrm{R}}$ on the right one) changes during holographic recording process, recording kinetic after light distribution shift (dashed vertical line) by half period.

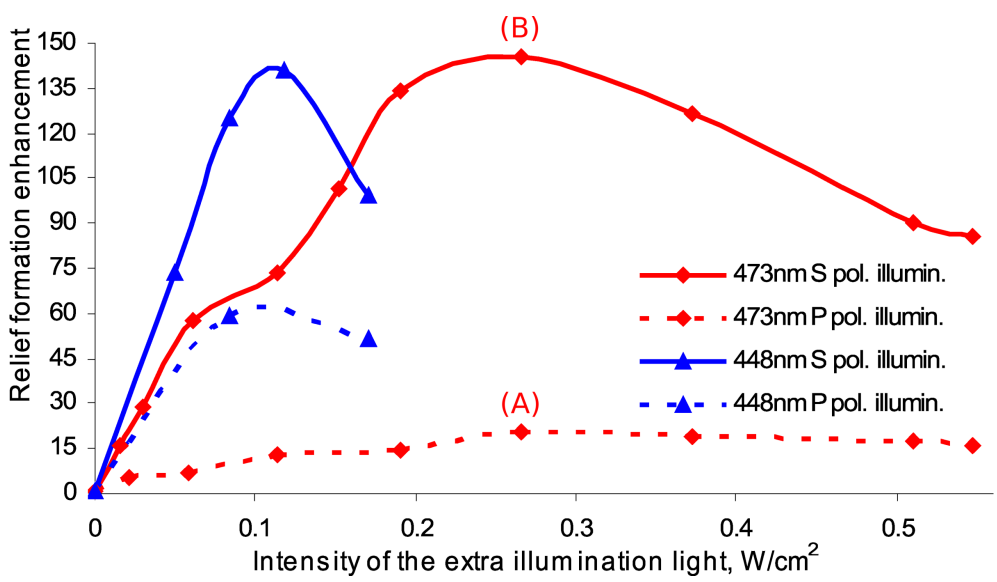

Fig. 3. Surface relief formation enhancement during holographic recording versus intensity of the extra illumination laser light (dots: experimental data) in the case of extra illumination at different wavelengths and polarization states of incoherent laser light (if $I_{\text {extra }}=0$ the relief formation enhancement equals one). Recording was performed by P \& P polarization state on $\mathrm{As}_{2} \mathrm{~S}_{3}$ sample by Verdi $6532 \mathrm{~nm}$ (P-polarized) wavelength laser light where $I_{1}=I_{2}=0.19 \mathrm{~W} / \mathrm{cm}^{2}$ and period $\Lambda=1 \mu \mathrm{m}$.

(softening by extra illumination) during holographic recording. Other recording parameters such as recording light, its intensity, and polarization state $(532 \mathrm{~nm}$, $0.2 \mathrm{~W} / \mathrm{cm}^{2}$, and P polarization) were kept constant.

First of all, in Fig. 3 we can see that the efficiency of surface relief formation is strongly changing at increasing intensity of extra illumination. Each curve in their linear part (up to $0.1 \mathrm{~W} / \mathrm{cm}^{2}$ for $448 \mathrm{~nm}$ extra illumination light and up to $0.2 \mathrm{~W} / \mathrm{cm}^{2}$ for $473 \mathrm{~nm}$ light) we can describe by its slope: for $473 \mathrm{~nm}$ $\mathrm{P}$-polarized extra illumination it is about $75 \mathrm{~W}^{-1} \mathrm{~cm}^{2}$, for $473 \mathrm{~nm} \mathrm{~S}$-polarized $675 \mathrm{~W}^{-1} \mathrm{~cm}^{2}$, for $448 \mathrm{~nm} \mathrm{P-}$ and S-polarized 64 and $1300 \mathrm{~W}^{-1} \mathrm{~cm}^{2}$. Here we can easily calculate our gains for the set-up parameters compared to the same set-up but without extra illumination during holographic recording. For example, by using $448 \mathrm{~nm}$ S-polarized $0.08 \mathrm{~W} / \mathrm{cm}^{2}$ wavelength light for extra illumination during experiment we can achieve the relief formation enhancement (proportional to $\eta_{\mathrm{R}}$ ) from one to about hundred $\left(1300 \mathrm{~W}^{-1} \mathrm{~cm}^{2}\right.$ multiplied by $0.08 \mathrm{~W} / \mathrm{cm}^{2}$ ).

These all curves somewhere reach their maxima. This means that for every laser light wavelength used for extra illumination there exist conditions for the best recording. By varying the wavelength of extra illumination light we can change its intensity to reach the best performance. As could be seen from Fig. 3, at changing $\lambda$ from 448 to $473 \mathrm{~nm}$ the best performance is reached when $I_{473 \mathrm{~nm}}=0.26 \mathrm{~W} / \mathrm{cm}^{2}$, which is different from the $448 \mathrm{~nm}$ case $\left(I_{448 \mathrm{~nm}}=0.11 \mathrm{~W} / \mathrm{cm}^{2}\right)$. This can be explained by the fact that $473 \mathrm{~nm}$ is closer to absorption edge of the sample, i. e. for the same effect we need to illuminate it by the light of higher intensity.

Here (Fig. 3, recording by P \& P-polarized light) we see that the recording efficiency depends not only on the extra illumination wavelength and its intensity but also on its polarization state. In the case of all extra illumination wavelengths ( 448 and $473 \mathrm{~nm}$ ) the best performance is reached at their $\mathrm{S}$ polarization state. In fact, 
Table 1. Surface relief formation efficiency during holographic recording $\left(\Delta \eta_{\mathrm{R}} / \Delta t\right)$ versus polarization state of extra illumination $\left(473 \mathrm{~nm} 0.26 \mathrm{~W} / \mathrm{cm}^{2}\right.$ incoherent laser light) and recording laser light. The recording performed on $\mathrm{As}_{2} \mathrm{~S}_{3}$ sample by Verdi 6 $532 \mathrm{~nm}$ (P-polarized) laser light $\left(I_{1}=I_{2}=\right.$ $\left.0.25 \mathrm{~W} / \mathrm{cm}^{2}, \Lambda=1 \mu \mathrm{m}\right)$.

\begin{tabular}{cccc}
\hline $\begin{array}{c}\text { Extra } \\
\text { illumin. } \\
\text { polariz. }\end{array}$ & $\begin{array}{c}\text { Rec. } \\
\text { polariz. }\end{array}$ & $\begin{array}{c}\Delta n_{R} / \Delta t, \\
10^{-7} \mathrm{~s}^{-1}\end{array}$ & $\begin{array}{c}\text { Relief } \\
\text { formation } \\
\text { enhancement }\end{array}$ \\
\hline S & P \& P & 13.7 & 260 \\
P & & 0.35 & 19 \\
- & & 0.22 & 2.2 \\
\hline S & S \& S & 19 & 190 \\
P & & 0.1 & 1 \\
- & & 0.17 & 4.3 \\
\hline S & S \& P & 0.035 & 0.88 \\
P & & 0.04 & 1 \\
- & & 23 & 32 \\
\hline S & $45 \& 45$ & 0.2 & 0.28 \\
P & & 0.72 & 1 \\
- & & 102 & 2.3 \\
\hline S & & 90.4 & 2 \\
P & $45 \&-45$ & 44 & 1 \\
- & & 98 & 2.2 \\
45 & & 58 & 0.64 \\
\hline S & & 62 & 0.69 \\
P & L \& R & 90 & 1 \\
- & & 57 & 100 \\
\hline S & L \& L & 0.25 & 0.44 \\
P & or & 0.57 & 1 \\
- & R R & & \\
\hline & & & \\
\hline
\end{tabular}

we can introduce a constant coefficient $a_{0}$ greater than one that shows how many times the S-polarized light outperforms the P-polarized light (irrespective of its intensity). For example, we need just to change the extra $473 \mathrm{~nm}$ P-polarized illumination to S-polarized and we get a seven times better result (in the case of $448 \mathrm{~nm}$ it is about two times). Here we can see very well the anisotropic impact of the linearly polarized light on the sample, like the polarization-dependent deflection of $\mathrm{As}_{2} \mathrm{~S}_{3}$ flakes in [7].

Table 1 summarizes the data not only on P \& P-polarized recording light but also on all other polarization combinations. Here it is important to pay attention to the recording polarization state and the extra illumination polarization state for the maximum performance. As could be seen, the best recording performance without any extra illumination is reached by opposite circularly and $45 \&-45$ degree polarized light; however, when we start using extra illumination the sit- uation changes. First, we can see that in the case of $\mathrm{P} \& \mathrm{P}$ recording polarization an extra $\mathrm{S}$-polarized illumination is needed for the best performance, whereas in the $\mathrm{S} \& \mathrm{~S}$ case it is a P-polarized one; i. e., in each of the cases a cross-polarized extra illumination is required for equal linear recording polarization states. In these cases the enhancement of relief formation is changing from 1 (extra illumination not used) to $\sim 200$. If both recording beams are in 45 degree polarization state, by using $S$-polarized extra illumination we can reach an enhancement of surface relief formation up to 30 .

Different situation is at using cross-polarized recording beams for holographic recording. For -45 and 45 degree polarized recording beams all polarization states of the extra illumination give identical results for the best performance, i. e. whatever polarized light is used for extra illumination we get the same relief formation enhancement. When recording by S \& P-polarized light, we can get just four times better results by using S-polarized extra illumination.

In the case of circularly polarized recording lights, extra illumination gives an excellent result if both recording beams are polarized in the same direction and the extra illumination light is in S polarization state (enhancement of relief formation is changing from 1 to 100). If both recording beams are oppositely circularpolarized, the extra illumination just reduces the efficiency of surface relief formation.

Figure 4 shows the surface morphology AFM images induced by holographic recording. By $(*)$ the surface of the amorphous chalcogenide $\mathrm{As}_{2} \mathrm{~S}_{3}$ film before holographic recording is indicated, and (A), (B) show this surface after recording at extra illumination by $\mathrm{P}$ - and S-polarized light. Exact (A) and (B) positions (maximum performance set-up) are shown in Fig. 3, and the surface relief profile is represented in Fig. 5. As could be expected from Fig. 3, the surface relief is much more expressed in the case of S-polarized extra illumination.

\section{Conclusion}

The main conclusion that can be drawn from the results of this work is as follows. It is possible to raise the efficiency of holographic recording by extra illumination of the sample by incoherent laser light during the recording. In some cases even more than hundred times better recording efficiency could be reached. We can obtain much stronger diffraction than without extra illumination, or, alternatively, much less time is needed to reach the same diffraction efficiency as without extra illumination. 

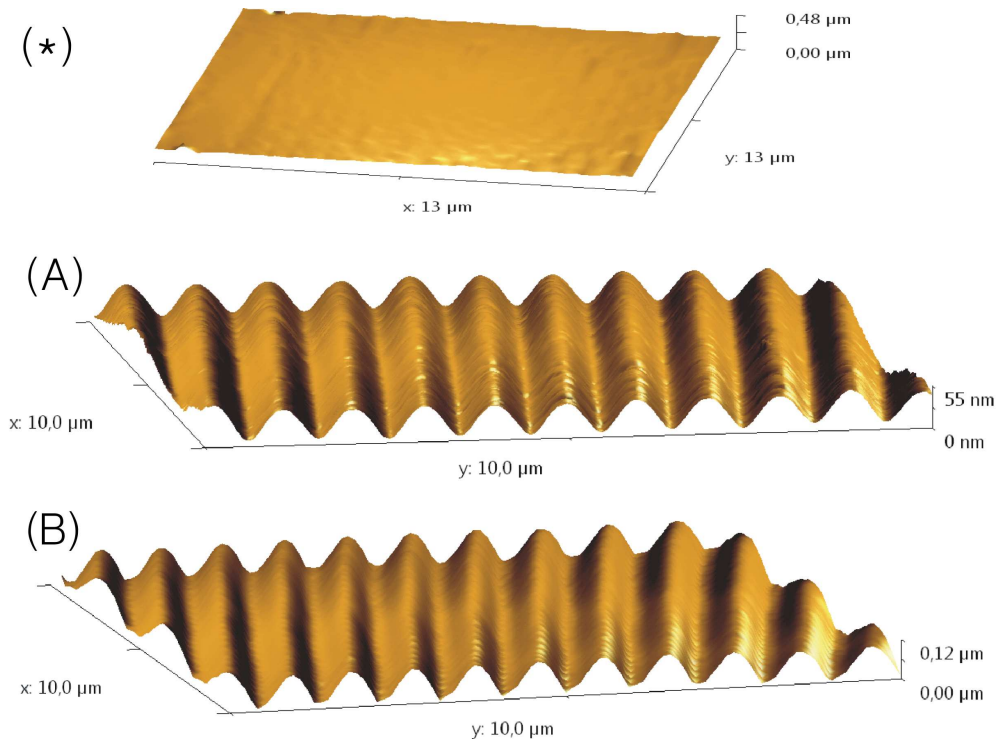

Fig. 4. AFM surface pictures of $(*)$ unexposed and (A, B) exposed parts of the sample. (A) and (B) parts were extra illuminated in real time by P-polarized and S-polarized $473 \mathrm{~nm}$ wavelength light (for (A) and (B) see also Figs. 3 and 5). The recording was performed on As $\mathrm{S}_{3}$ sample by Verdi $6532 \mathrm{~nm}$ (P-polarized) laser light $\left(I_{1}=I_{2}=0.19 \mathrm{~W} / \mathrm{cm}^{2}, I_{\text {extra }}=0.26 \mathrm{~W} / \mathrm{cm}^{2}\right.$, and $\left.\Lambda=1 \mu \mathrm{m}\right)$.

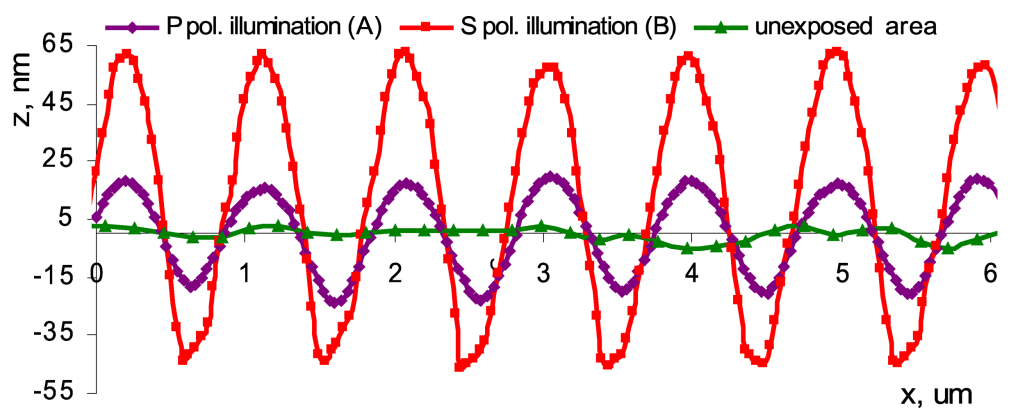

Fig. 5. Surface relief profile after recording at $532 \mathrm{~nm}$ wavelength P-polarized light $\left(I_{1}=I_{2}=0.19 \mathrm{~W} / \mathrm{cm}^{2}\right)$ in the case of extra illumination by $0.26 \mathrm{~W} / \mathrm{cm}^{2} 473 \mathrm{~nm}$ wavelength S-polarized (line representing relief with the largest amplitude changes) and P-polarized (line representing relief with medium amplitude changes) light and its comparison with unexposed spot of the sample (dots: experimental data).

\section{References}

[1] M.L. Trunov, S.N. Dub, P.M. Nagy, and S. Kokenyesi, J. Phys. Chem. Solids 68, 1062-1068 (2007).

[2] A. Kikineshi, V. Palyok, M. Shiplyak, I.A. Szabó, and D.L. Beke, J. Optoelectron. Adv. Mater. 2(1), 95-98 (2000).

[3] A. Csik, M. Malyovanik, J. Dorogovics, A. Kikineshi, D.L. Beke, I.A. Szabo, and G. Langer, J. Optoelectron. Adv. Mater. 3(1), 33-36 (2001).

[4] K. Tanaka, N. Terakado, and A. Saitoh, J. Optoelectron. Adv. Mater. 10(1), 124-130 (2008).

[5] A. Saliminia. T.V. Galstian, and A. Villeneuve, Phys. Rev. Lett. 85(19), 4112-4115 (2000).
[6] M.L. Trunov, JETP Lett. 86(5), 365-369 (2007).

[7] S. Kokenyesi, I. Iván, V. Takáts, J. Pálinkás, S. Biri, and I.A. Szabo, J. Non-Cryst. Solids 353, 1470-1473 (2007).

[8] B. Bellini, J. Ackermann, H. Klein, Ch. Grave, Ph. Dumas, and V. Safarov, J. Phys. Condens. Matter 18, S1817-S1835 (2006).

[9] K.E. Asatryan, T. Galstian, and R. Vallee, Phys. Rev. Lett. 94, 087401 (2005).

[10] A. Kikineshi, V. Palyok, I.A. Szabó, M. Shiplyak, I. Ivan, and D.L. Beke, J. Non-Cryst. Solids 326-327, 484-488 (2003). 


\title{
ŠVIESA INDUKUOJAMA PAVIRŠIAUS RELJEFO MODULIACIJA AMORFINĖSE CHALKOGENIDŲ PLĖVELĖSE HOLOGRAFINIO İRAŠYMO METU
}

\author{
U. Gertners, J. Teteris
}

Latvijos universiteto Kietojo kūno fizikos institutas, Ryga, Latvija

\begin{abstract}
Santrauka
Nagrinèta paviršinio reljefo gardelių, tiesiogiai holografiškai i̊rašomų ant amorfinių chalkogenidų plèvelių $(0,5-10 \mu \mathrm{m}$ storio), priklausomybė nuo šviesos poliarizacijos. Buvo ịrašoma ant $\mathrm{As}_{2} \mathrm{~S}_{3}$ su $532 \mathrm{~nm}$ šviesos bangos ilgio lazeriu. Kadangi paviršiaus reljefas yra formuojamas tiesiogiai, tai efektyvumas taip pat gali pri-
\end{abstract}

klausyti nuo plèvelès medžiagos minkštėjimo temperatūros. Todèl holografinio įrašymo metu buvo naudojama papildoma nekoherentinè lazerio šviesa. Rezultatai parodè, kad tuomet paviršiaus reljefo formavimasis yra daug kartu efektyvesnis. Aptariamas tiesioginio paviršiaus reljefo įrašymo ant amorfinių chalkogenido plèvelių mechanizmas, kuris pagrịstas fotoindukuotu plastiškumu. 